\title{
FACTORS AFFECTING THE UPTAKE OF LISSAMINE GREEN BY SERUM PROTEINS *
}

\author{
BY \\ C. J. BRACKENRIDGE \\ From the Biochemistry Department, Royal Perth Hospital, Perth, Western Australia
}

(RECEIVED FOR PUBLICATION JUNE 16, 1959)

Eight physicochemical factors which affect the uptake of lissamine green on filter paper impregnated with serum proteins have been examined, and their relevance to the staining of electrophoretically separated protein fractions is discussed. It is shown that grade of paper, weight of protein applied, separate and combined denaturation and staining time, temperature and concentration of staining solution, concentration of denaturant, and type of protein all influence the weight of dye absorbed per unit weight of applied protein, and must be rigidly standardized if valid quantitative results are to be obtained.

Five sets of conditions are obtained for optimal staining and it is found that separation of denaturant from dye yields the best procedure. It is concluded that lissamine green is an excellent dye for the staining and quantitative estimation of separated protein fractions in paper electrophoresis, and that conditions can usually be arranged to produce a linear relation between dye uptake and protein concentration in an experimentally efficient manner.

Despite the large number of publications dealing with the separation and staining of serum proteins by paper electrophoresis, there is a relative paucity of information concerning the role of physicochemical factors. McDonald $(1952,1955)$, McDonald, Urbin, and Williamson (1951), McDonald, Lappe, Marbach, Spitzer, and Urbin (1953), and McDonald, Foresman, and Bermes (1957) have shown how such variables as temperature and voltage affect the mobility, while studies such as those of Franglen and Martin (1954), Jencks, Jetton, and Durrum (1955), Franglen (1956) and Henry, Golub, and Sobel (1957) indicate the complexity of the numerous entities influencing the uptake of dye by the separated components.

One result has been to demonstrate the deficiencies of some dyes and the advantages of others. Thus lissamine green has come to be favoured by many workers (Discombe, Jones, and Winstanley, 1954; Abdel-Wahab and Laurence, 1955 ; Dangerfield and Smith, 1955 ; Rideout and Prichard, 1955 ; Gilliland, Johnston, Stradling, and Abdel-Wahab, 1956 ; Owen, 1956 ; Gorringe, 1957 ; Rappaport, Eichhorn, and Fischl, 1957). Unfortunately, most of the dyes studied under the conditions reported to date suffer from some draw-

\footnotetext{
* Presented, in part, at the Perth Meeting of the Australian Biochemical Society. August, 1959.
}

back such as variation of dye uptake with protein fraction. This has led to the use of correction factors in some quarters (Cremer and Tiselius, 1950 ; Köiw, Wallenius, and Grönwall, 1952) ; but their adoption has been questioned on the ground that there is no adequate standard for comparison (Owen, 1956).

Accordingly, claims that bromophenol blue (Hardwicke, 1954) and lissamine green (Gorringe, 1957) have the same binding capacity for the different protein fractions merit close consideration. The object of the present study is to examine some physicochemical variables affecting the uptake of lissamine green and thus test its suitability as a stain in paper electrophoresis.

\section{Materials and Methods}

Protein Solutions.-Solutions of whole serum, albumin, and $\gamma$-globulin were prepared by dilution with $0.9 \%$ sodium chloride solution. The electrophoretic analysis of the latter two fractions was very satisfactory. Pooled normal human serum $\dagger$ containing merthiolate as preservative, normal human serum albumin $\ddagger$, buffered and concentrated, and normal human serum $\gamma$-globulin $\ddagger$ containing merthiolate as additive were used. Stock solutions were standardized both by a biuret copper sulphate method and a micro-

\footnotetext{
$\dagger$ By courtesy of the Australian Red Cross Society, Western $\dagger$ By courtesy of
Australian Division.

$\ddagger$ Commonwealth Serum Laboratories, Melbourne, Victoria.
} 
Kjeldahl method in which a conversion factor of 6.54 was employed (Sunderman, Sunderman, Falvo, and Kallick, 1958).

Paper.-In general, Whatman No. 3MM filter paper was used throughout this work. To study the effects of other grades, Whatman Nos. 2 and 3 were also tested.

Dye-Lissamine green S.F. $150^{*}$ was the sole dye used. Although chromatography reveals the presence of several components, Gorringe (1957) tested seven batches and found the dye to behave similarly in every respect, as did also one batch after repeated use. Its excellent reproducibility has been confirmed in this laboratory.

Eluent.-The elution buffer of $p H 6.0$ recommended by Gorringe (1957) was adopted; it proved to act more rapidly than $40 \%$ acetic acid which Owen (1956) used. Solutions of the dye were found to be stable at room temperature for several days.

Absorbance Measurements.-A calibration line of dye concentration versus optical density was constructed with solutions of dye in the elution buffer using a Hilger "uvispek" quartz spectrophotometer and $1 \mathrm{~cm}$. cells. Beer's law was obeyed over the concentration range studied (0-20.5 $\mu \mathrm{g}$. per $\mathrm{ml}$.) at $635 \mathrm{~m} \mu$, the wavelength of maximum absorption. The relation $\mathrm{C}=20.9 \mathrm{D}$ fitted the experimental data to within $\pm 2 \%$, where $\mathrm{C}$ is the dye concentration in $\mu \mathrm{g}$. per $\mathrm{ml}$. and $\mathrm{D}$ is the optical density.

Staining Process.-To filter paper strips, $10 \mu \mathrm{l}$. amounts of protein solution were added from a micropipette so as to form circular areas. The dimensions were found to vary with the concentration. When the spots had dried, the protein was denatured and stained. This was done either simultaneously by immersing for a given time in a solution of dye in $3 \%$ aqueous salicylsulphonic acid, or separately by dipping in 3\% aqueous salicylsulphonic acid for at least 15 minutes and staining in an aqueous dye bath. This was preferred to heat denaturation in the belief that more control would be gained. Thus Henry et al. (1957) proved that "time and temperature of heat-fixation are critical variables " and "their close control is essential for reproducible results." Excess dye was removed with four washings of $2 \%$ acetic acid solution $(v / v)$ in water followed by two rinsings in distilled water. The strips then had a perfectly white background and were dried at $30^{\circ} \mathrm{C}$.

Dye Uptake Measurements.-Areas of dye spots were calculated by circumscribing 10 times with a planimeter. The spots were then cut out and placed in a measured volume of eluent. Identical areas of background paper provided blanks. When elution was complete, the optical density of each solution was measured and the amount of dye calculated from the calibration equation. All measurements were performed in triplicate and the mean taken.

* Imperial Chemical Industries Ltd., Dyestuffs Division.

\section{Results}

The following results describe the effects on lissamine green absorption of (1) grade of filter paper, (2) weight of protein applied, (3) combined denaturation-staining time, (4) concentration of dye, (5) combined denaturation-staining temperature, (6) concentration of salicylsulphonic acid, (7) protein fraction, and (8) separate times of denaturation and staining.

Effect of Grade of Paper.-To test the effect of different types of Whatman filter paper, three $10 \mu \mathrm{l}$. volumes of serum protein of concentration $5.22 \mathrm{~g}$. per $100 \mathrm{ml}$. were pipetted on to each of Nos. 2, 3, and 3MM grade papers. After combined denaturation-staining, the areas of the protein spots were determined by planimetry. They were then eluted and the weights of dye absorbed per square $\mathrm{cm}$. evaluated. The results are shown in Table $I$.

TABLE I

EFFECT OF GRADE OF FILTER PAPER ON DYE UPTAKE

\begin{tabular}{|c|c|c|c|c|}
\hline $\begin{array}{l}\text { Grade of } \\
\text { Paper }\end{array}$ & 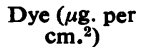 & $\begin{array}{c}\text { Area of Spread } \\
\left(\mathrm{cm} .^{2}\right)\end{array}$ & Thickness & Roughness \\
\hline $\begin{array}{l}2 \\
3 \mathrm{MM} \\
3\end{array}$ & $\begin{array}{r}82 \cdot 4 \pm 0.8 \\
117 \cdot 4 \pm 2 \cdot 1 \\
161 \cdot 3 \pm 4 \cdot 6\end{array}$ & $\begin{array}{l}1.062 \pm 0.026 \\
0.647 \pm 0.005 \\
0.505 \pm 0.008\end{array}$ & $\begin{array}{c}+ \\
++ \\
+++\end{array}$ & $\begin{array}{c}+ \\
++ \\
++t\end{array}$ \\
\hline
\end{tabular}

The weight of dye absorbed per unit area when $10 \mu \mathrm{l}$. of serum was added to various grades of Whatman filter paper is compared quantitatively with the area of spread and qualitatively with the quantitatively with the area of spread and qualitatively with the per $100 \mathrm{ml}$. Numerical values indicate the range of triplicate measurements. The dye concentration was $200 \mathrm{mg}$. per $100 \mathrm{ml}$. of $3 \%$ aqueous salicylsulphonic acid, the staining time one hour, and the temperature $20^{\circ} \mathrm{C}$.

It is apparent that the highest dye uptake is on grade 3 paper, which also gives rise to the smallest protein area. In quantitation by elution, the advantage of a high uptake is somewhat offset by $ᄋ$ the smaller area and thicker paper to be cut out. I Moreover, there is the densitometric disadvantage that No. 3 paper is the roughest and hence the least uniform in surface properties. These factors $\sigma$ must be borne in mind when choosing a grade of $N$ paper; in the present study a middle course was $\underset{\omega}{N}$ taken and grade $3 \mathrm{MM}$ was selected for use.

Effect of Weight of Protein.-There are two ways of applying quantities of protein to paper. The first is to pipette varying volumes of a fixed concentration of protein solution; the second is to pipette a fixed volume of varying concentrations. The weight of dye absorbed per unit area by both these procedures is shown in Fig. 1. The $\varrho$ curves are similar to a concentration of $300 \mu \mathrm{g}$. per sq. $\mathrm{cm}$. 


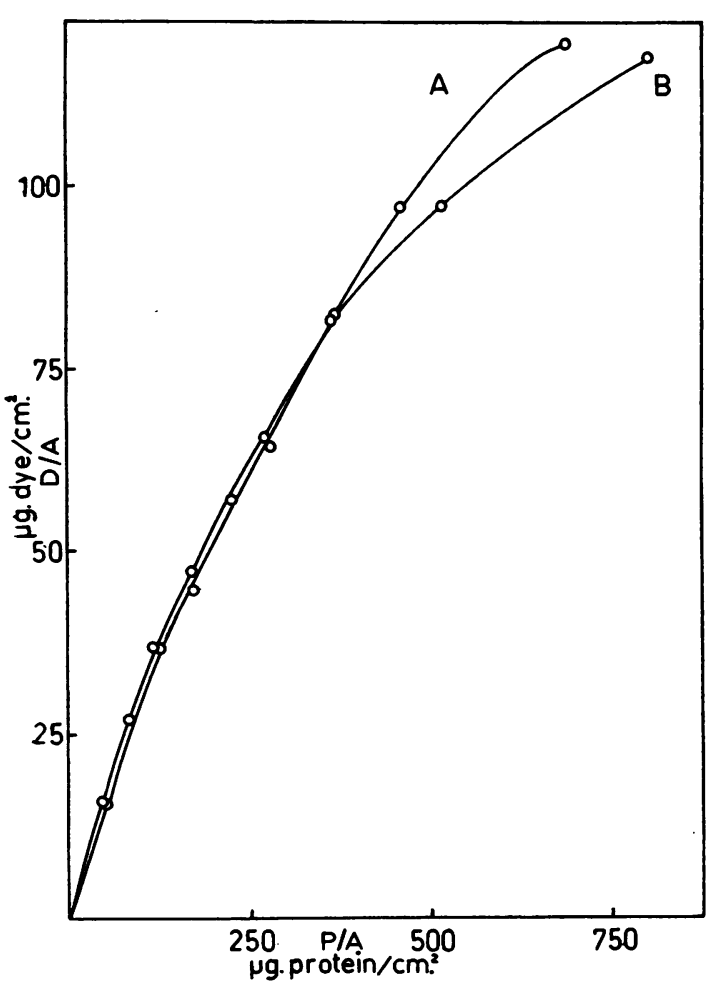

FIG. 1.-Variation of weight of lissamine green absorbed per sq. $\mathrm{cm}$. of paper (D/A) with weight of protein in $\mu \mathrm{g}$. applied per sq. $\mathrm{cm}$. (P/A). Curve A was obtained by adding various volumes of a fixed protein concentration; curve B was obtained by adding a fixed volume of various protein concentrations. Experimental conditions are described in the text.

In Fig. 2 the ratio of the weight of dye absorbed to the weight of protein applied $(D / P)$ is expressed as a function of $(a)$ area of spot, $(b)$ volume of solution pipetted, and $(c)$ weight of protein applied. The areas and volumes in $(a)$ and $(b)$, respectively, were those used in drawing the fixed concentration curve A of Fig. 1 . The values in Fig. 2(c) were those used in drawing the fixed volume curve $B$ of Fig. 1. The conditions employed in obtaining the data of Figs. 1 and 2 were as follows: Dye concentration: $200 \mathrm{mg}$. per $100 \mathrm{ml}$. of $3 \%$ aqueous salicylsulphonic acid; denaturation-staining time: one hour; temperature : $20^{\circ} \mathrm{C}$.

As the protein density rises, the dye molecules find it increasingly difficult to occupy the diminishing number of vacant interstices in the paper. Since $P, V$, and $A$ are all mutually proportional, the progressive decrease of the dyeprotein ratio in each case is to be expected. Similar observations have been made by Gorringe (1957).
Effect of Time.-The ratio of the weight of dye absorbed to the weight of protein applied (D/P) at various protein concentrations under conditions combining denaturation with staining was measured at intervals of $5,10,15,30,45,60$, 150 minutes, and 24 hours.

From an electrophoretic point of view, the ratio of the weight of dye absorbed to the weight of protein applied (the dye-protein ratio, $\mathbf{D} / \mathbf{P}$ ) is a more significant quantity than the weight of dye absorbed per sq. $\mathrm{cm}$. (the dye uptake, D/A) for the determination of optimal staining conditions. (If elution is preferred to direct densitometry, calculation of the area $A$ is superfluous.) When the dye-protein ratio is identical for all protein concentrations, then the dye uptake is directly related to the weight of protein applied. An even more favourable circumstance occurs when the
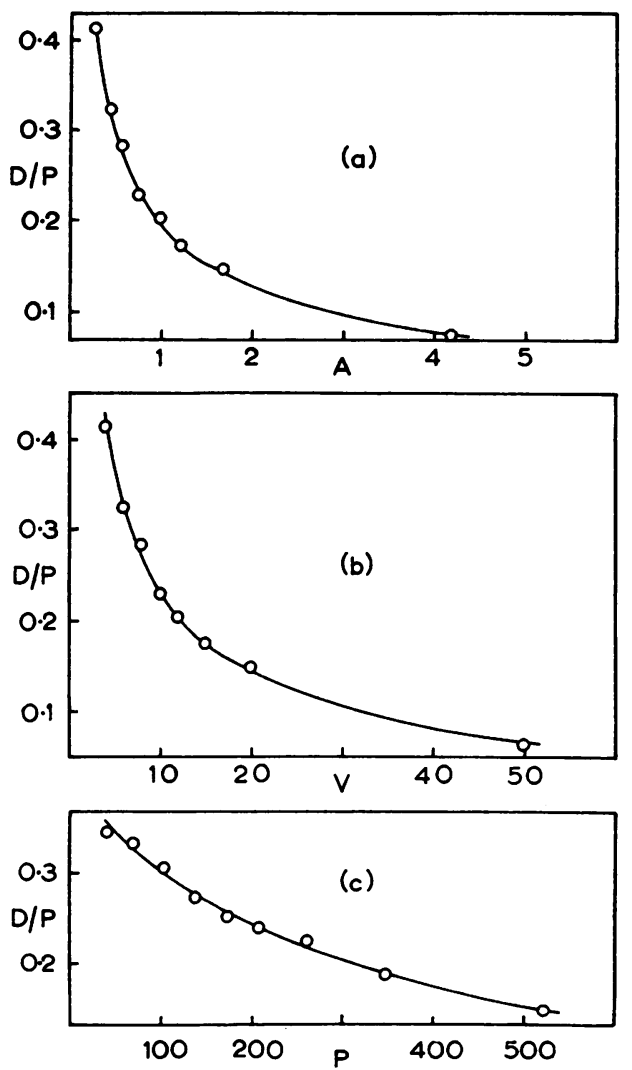

FIG. 2.-Variations of ratio of weight of lissamine green absorbed to the weight of protein applied $(D / P)$ with $(a)$ area in sq. $\mathrm{cm}$. (A) covered ry variuus volumes of a $2.09 \mathrm{~g}$. per $100 \mathrm{ml}$. protein solution, (b) volume in $\mu \mathrm{i}$. (V) of a $2.09 \mathrm{~g}$. per $100 \mathrm{ml}$. protein solution, and $(c)$ weight in $\mu \mathrm{g}$. (P) of protein applied at a fixed volume of $10 \mu \mathrm{l}$. Experimental conditions are described in the text. 


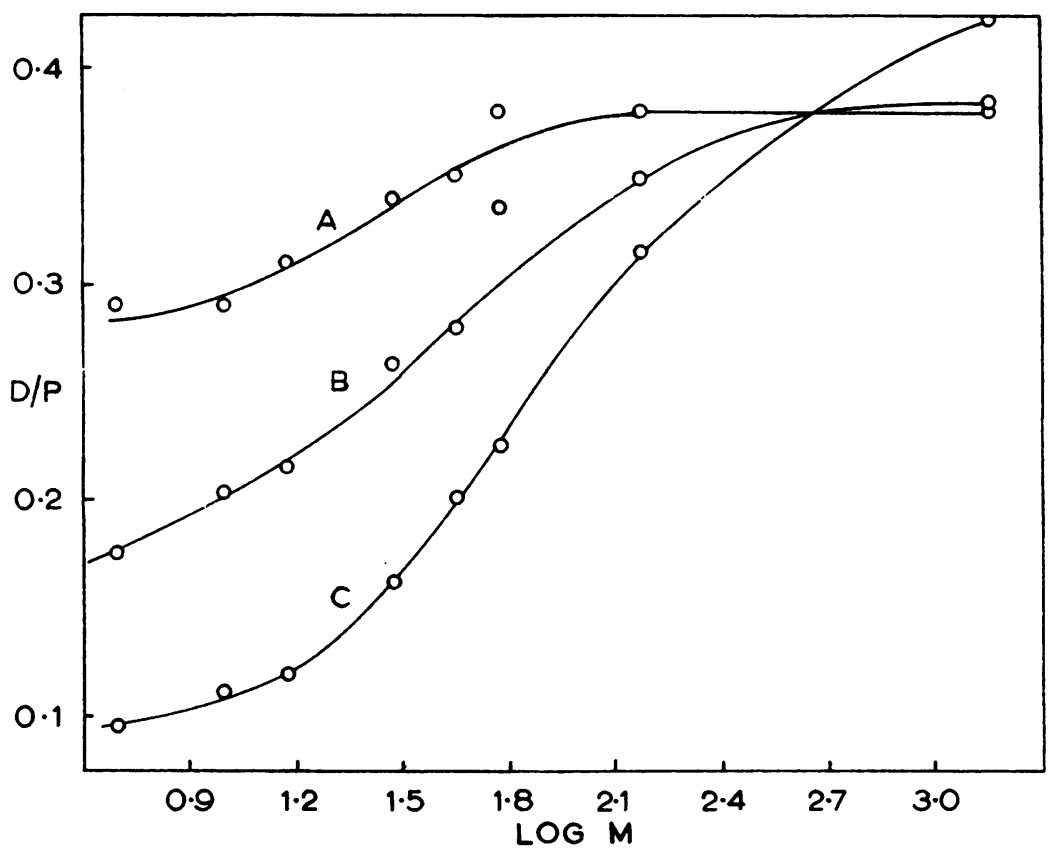

FIG. 3.-Variation of the dye-protein ratio (D/P) with the logarithm of the time in minutes (M) during which combined denaturation-staining took place. Curve A denotes a protein concentration of $0.21 \mathrm{~g}$. per $100 \mathrm{ml}$.; curve B $1.04 \mathrm{~g}$. per $100 \mathrm{ml}$.; and curve C $5.22 \mathrm{~g}$. per $100 \mathrm{ml}$. Experimental conditions are described in the text.

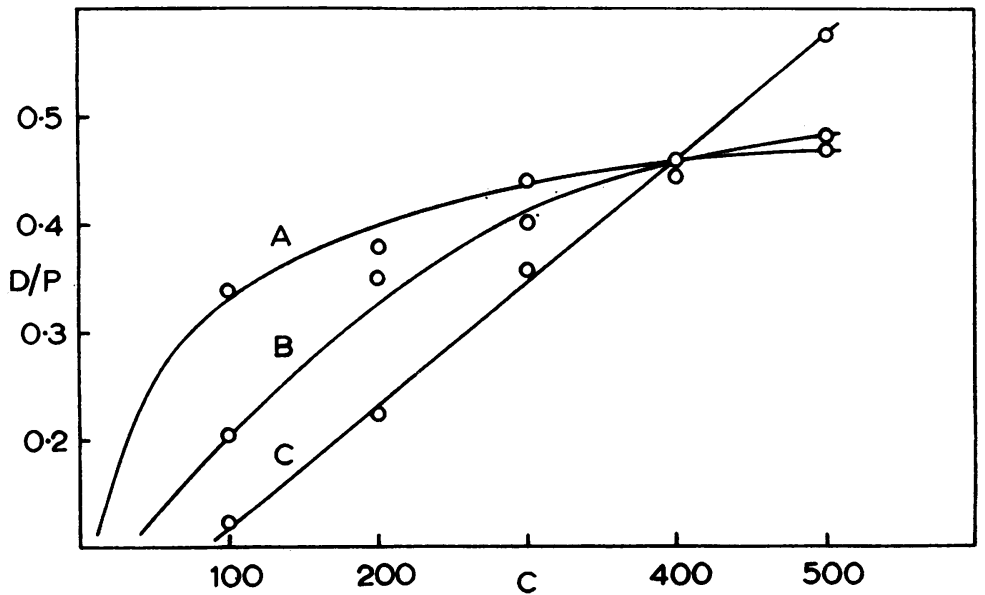

FIG. 4.-Variation of the dye-protein ratio $(D / P)$ with the lissamine green concentration $(C)$ in mg. per $100 \mathrm{ml}$. at protein concentrations of A: 0.21 g. per $100 \mathrm{ml}$, B: $1.04 \mathrm{~g}$. per $100 \mathrm{ml}$., and C: $5.22 \mathrm{~g}$. per $100 \mathrm{ml}$. Experimental conditions are described in the text.

dye-protein ratio is the same for all serum protein fractions.

Fig. 3 indicates the time-dependence of the dyeprotein ratio at three protein concentrations. (The abscissa has been plotted in common logarithms to compress the scale.) The ratio becomes independent of protein concentration at approximately $\mathbf{4 7 0}$ minutes. The dye concentration was
$200 \mathrm{mg}$. per $100 \mathrm{ml}$ of $3 \%$ aqueous salicylsulphonic $\stackrel{\oplus}{\oplus}$ acid, and the temperature $20^{\circ} \mathrm{C}$.

Effect of Dye Concentration.-Fig. 4 demonstrates the effect of varying the concentration of lissamine green in mg. per $100 \mathrm{ml}$. of $3 \%$ aqueous $\stackrel{\mathbb{Q}}{\Omega}$ salicylsulphonic acid on the dye-protein ratioat three protein concentrations. Denaturationstaining was carried out for one hour at $20^{\circ} \mathrm{C}$ 


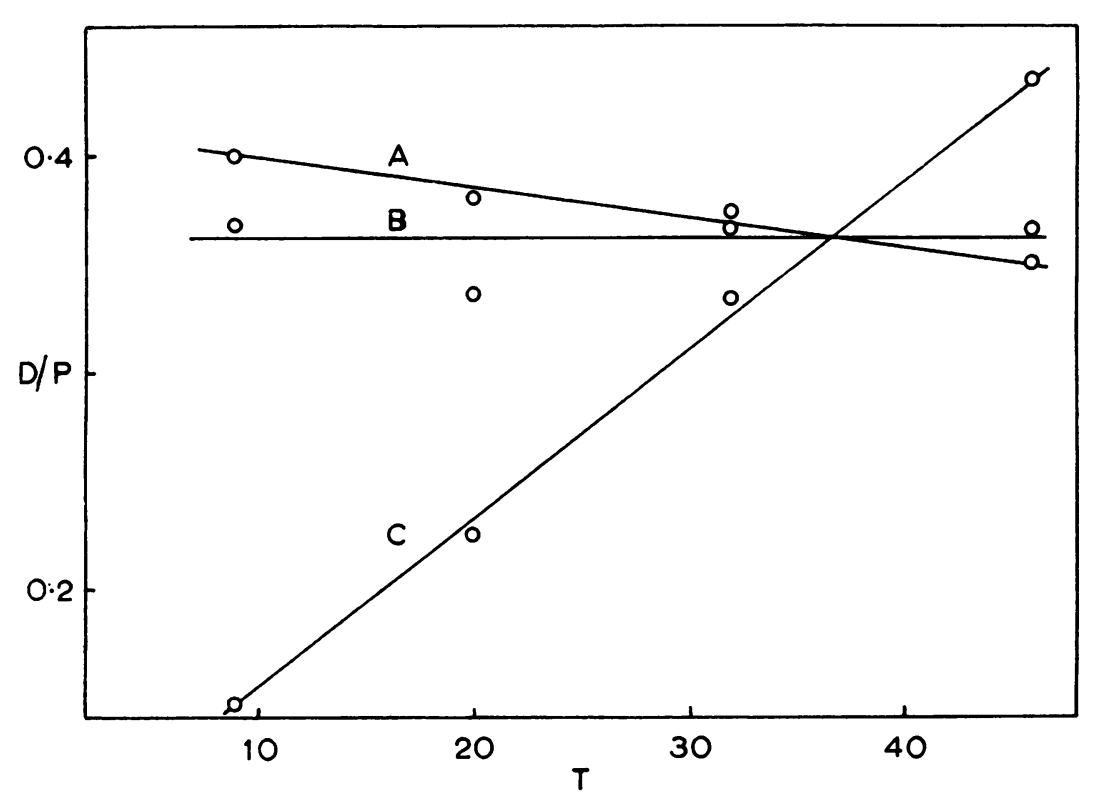

FIG. 5. - Variation of the dye-protein ratio $(D / P)$ with the centigrade temperature $(T)$ at protein concentrations of A: $0.21 \mathrm{~g}$. per $100 \mathrm{ml}$., B: $1.04 \mathrm{~g}$. per $100 \mathrm{ml}$, and C: $5.22 \mathrm{~g}$. per $100 \mathrm{ml}$. Experimental conditions are described in the text.

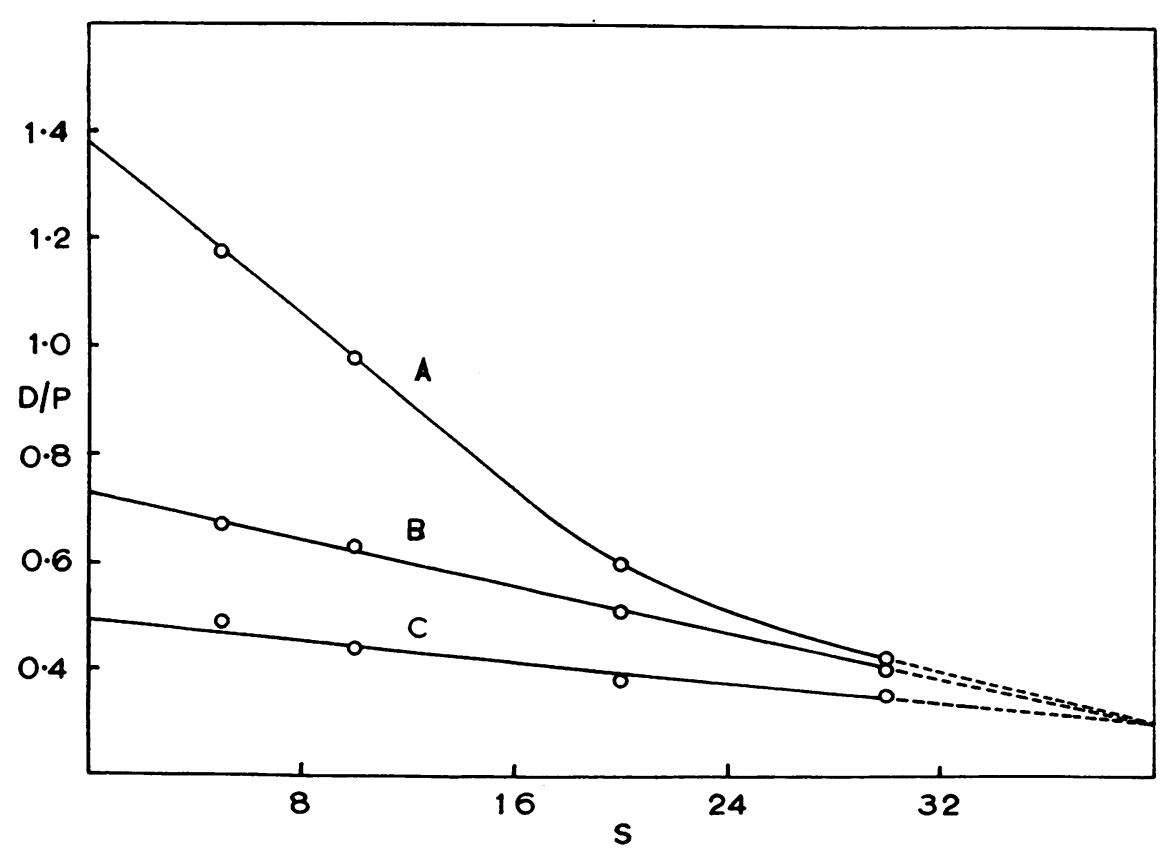

FIG. 6.-Variation of the dye-protein ratio (D/P) with the salicylsulphonic acid concentration (S) in $g$. per litre at protein concentrations of A: $5.22 \mathrm{~g}$. per $100 \mathrm{ml}$, B: $1.04 \mathrm{~g}$. per $100 \mathrm{ml}$, and C: $0.21 \mathrm{~g}$. per $100 \mathrm{ml}$. Experimental conditions are described in the text. 
The point of intersection occurs at a dye concentration of about $410 \mathrm{mg}$. per $100 \mathrm{ml}$.

Effect of Temperature.-The dye-protein ratio is seen in Fig. 5 to vary with the temperature of denaturation-staining at the three specified protein concentrations. The dye concentration was 200 mg. per $100 \mathrm{ml}$. of $3 \%$ aqueous salicylsulphonic acid and the time of denaturation-staining was one hour. Under these conditions an optimal temperature of $36^{\circ} \mathrm{C}$. was obtained.

Effect of Salicylsulphonic Acid Concentration.Fig. 6 shows the dependence of the dye-protein ratio on the concentration of salicylsulphonic acid at various protein concentrations. The dye concentration was $200 \mathrm{mg}$. per $100 \mathrm{ml}$. of aqueous salicylsulphonic acid, the denaturation-staining time was 24 hours and the temperature $24^{\circ} \mathrm{C}$. Extrapolation leads to an approximate value of 40 g. per litre for the optimal acid concentration.

Effect of Protein Fraction.-In view of the preceding results, some of the experimental conditions were altered to gain increased staining

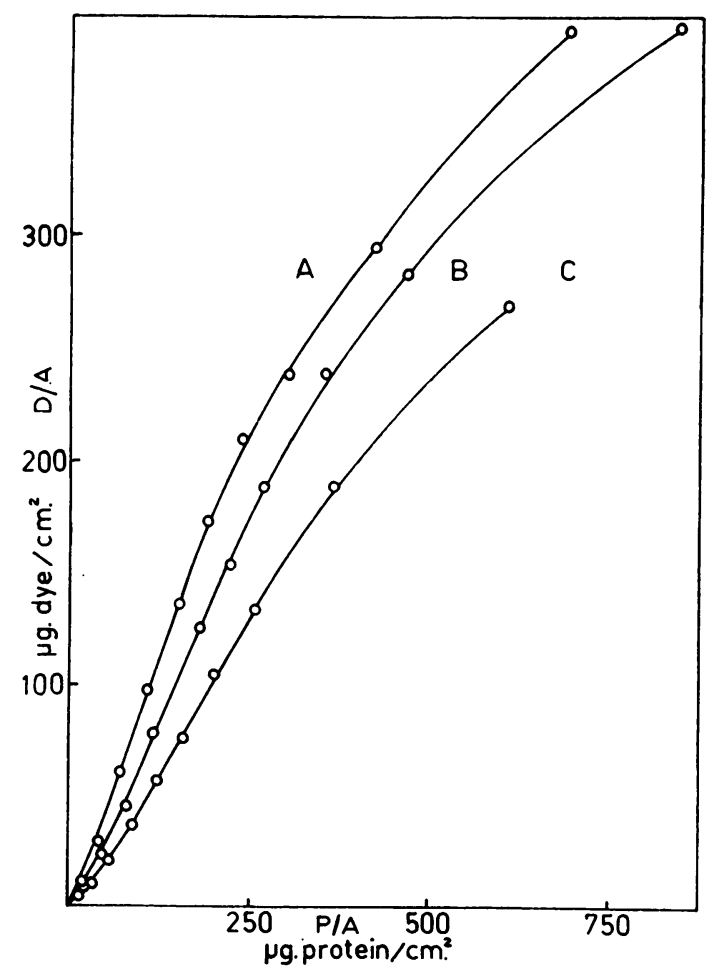

FIG. 7.-Variation of weight of lissamine green absorbed per sq. $\mathrm{cm}$. of paper (D/A) with weight of protein in $\mu \mathrm{g}$. applied per sq. $\mathrm{cm}$. (P/A) for A: albumin, B: whole serum, and C: $\gamma$-globulin. Experimental conditions are described in the text. efficiency. Using a reduced salicylsulphonic acid 은 content in the combined denaturation-staining $\overrightarrow{\overrightarrow{\vec{\omega}}}$ solution, the dye uptakes of whole serum, albumin, $\overrightarrow{0}$ and $\gamma$-globulin were measured. The results are $\frac{}{0}$ shown in Fig. 7 for which the following conditions $\overline{\bar{\omega}}$. pertained: Dye concentration: $200 \mathrm{mg}$. per $100 \widehat{\widehat{D}}$ $\mathrm{ml}$. of $0.5 \%$ aqueous salicylsulphonic acid $\stackrel{2}{0}$ denaturation-staining time: one hour; tempera- $\infty$ ture : $21^{\circ} \mathrm{C}$.

Effect of Separate Denaturation and Staining. $-\overrightarrow{\vec{H}}$ In order to obtain quantitative data on the ${ }_{\mathscr{\rho}}$ differential effect between combined and separate denaturation and staining on the dye-protein ratio, the following experiment was performed. Before $\omega$ being stained for $15,30,45,60,150$ minutes, and $\stackrel{N}{-}$ 24 hours, various quantities of protein were $\vec{c}$ denatured on paper in a salicylsulphonic acid 의

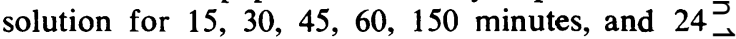
hours for each staining time.

The results showed that, within experimental error, the dye uptake at a particular staining time $\stackrel{\rho}{\mathcal{S}}$ was independent of the time of denaturation. $\vec{\theta}$ Thus denaturation was complete within 15 minutes for the complete range of protein concentrations studied $(0.21$ to $5.22 \mathrm{~g}$. per $100 \mathrm{ml}$.) under the following conditions: Dye concentration: 200 mg. per $100 \mathrm{ml}$. of water ; temperature: $17^{\circ} \mathrm{C}$.; salicylsulphonic acid concentration: $30 \mathrm{~g}$. per $\frac{\square}{\Phi}$ litre. Fig. 8 shows the variation of the dye- $\varrho$ protein ratio with the logarithm of the time of $\overrightarrow{\overrightarrow{0}}$ staining in minutes after denaturation for 153 minutes. The conditions were those described in this section, and results were obtained at five protein concentrations. The optimal staining time is 횽 attained after approximately 23 minutes.

Table II summarizes the five sets of optimal 3 conditions determined in these studies.

TABLE II

SUMMARY OF OPTIMAL STAINING CONDITIONS

\begin{tabular}{|c|c|c|c|c|c|}
\hline $\begin{array}{l}\text { Dye } \\
\text { Concen- } \\
\text { tration } \\
\text { (mg./100 } \\
\text { ml.) }\end{array}$ & $\begin{array}{c}\text { Tem- } \\
\text { pera+ure } \\
\left({ }^{\circ} \mathrm{C} .\right)\end{array}$ & $\begin{array}{l}\text { Time } \\
\text { (min.) }\end{array}$ & $\begin{array}{l}\text { Salicyl- } \\
\text { sulphonic } \\
\text { Acid Con- } \\
\text { centration } \\
\text { (g.'litre) }\end{array}$ & $\begin{array}{c}\text { Separate } \\
\text { or } \\
\text { Combined } \\
\text { Staining }\end{array}$ & $\begin{array}{c}\text { Dye- } \\
\text { Protein } \\
\text { Ratio at } \\
\text { Optimal } \\
\text { Condition }\end{array}$ \\
\hline $\begin{array}{l}410^{*} \\
200 \\
200 \\
200 \\
200\end{array}$ & $\begin{array}{l}20 \\
36 * \\
17 \\
20 \\
24\end{array}$ & $\begin{array}{c}60 \\
60 \\
23^{*} \\
470^{*} \\
1,440^{*}\end{array}$ & $\begin{array}{l}30 \\
30 \\
30 \\
30 \\
40^{*}\end{array}$ & $\begin{array}{c}\text { Combined } \\
\text {,, } \\
\text { Separate } \\
\text { Combined } \\
\text {,, }\end{array}$ & $\begin{array}{l}0.46 \\
0.36 \\
0.35 \\
0.38 \\
0.30\end{array}$ \\
\hline
\end{tabular}

\section{Discussion}

It is clear that, under the conditions described, linearity of dye uptake with protein concentration $\stackrel{\odot}{\Phi}$ has not been obtained. Further, the uptakes of $\stackrel{\mathbb{Q}}{\varrho}$ normal human serum, albumin, and $\gamma$-globulin differ appreciably, the order of increasing uptake 


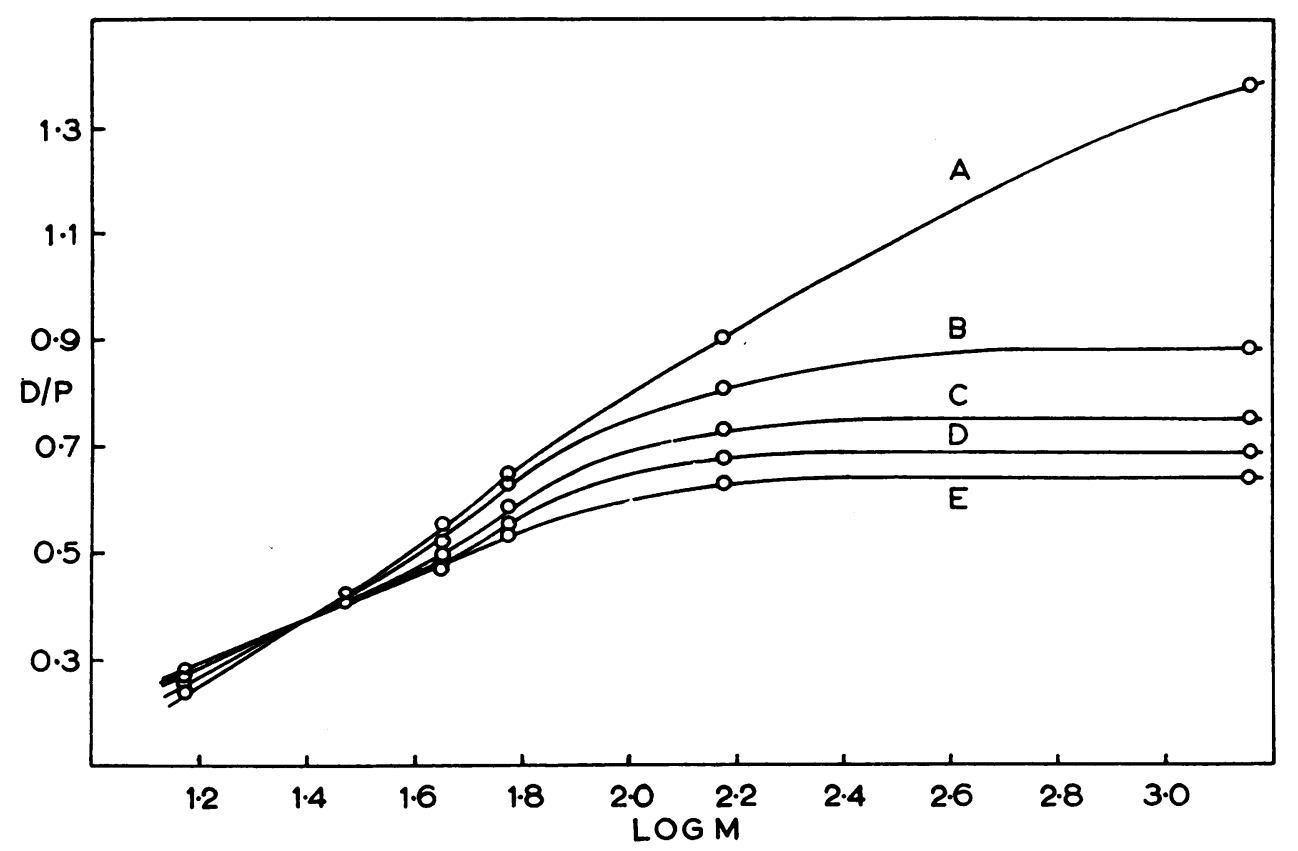

Fig. 8.-Variation of the dye-protein ratio (D/P) with the logarithm of the time in minutes (M) during which staining took place at the following protein concentrations. A: $5.22 \mathrm{~g}$. per $100 \mathrm{ml}$., B: $3.48 \mathrm{~g}$. per $100 \mathrm{ml}$., C: $2.09 \mathrm{~g}$. per $100 \mathrm{ml}$., D: $1.04 \mathrm{~g}$. per $100 \mathrm{ml}$, and E: $0.21 \mathrm{~g}$. per $100 \mathrm{ml}$. Experimental conditions are described in the text.

being $\gamma$-globulin, whole serum and albumin (Figs. 1,7). This agrees with the order observed by Gorringe (1957) at high lissamine green concentrations, and by Jencks et al. (1955) with bromophenol blue. Nevertheless, it is plain that conditions can usually be determined under which linearity of uptake can be accomplished over a large concentration range for a given fraction (Table II). Whether such conditions yield identical results for every fraction requires further experimentation; it involves the assumption that the staining properties of the applied commercial fractions and the separated physiological fractions are identical.

Comparison of Figs. 3 and 8 proves that greater staining efficiency is realized when dye and denaturant are separated. This is due to the adverse effect on the dye-protein ratio of increasing concentrations of the acid denaturant (Fig. 6). The expected correlation between uptake and dye concentration leads to the highest optimal dyeprotein ratio of 0.46 obtained in these studies (Fig. 4, Table II); however, in terms of dye-protein ratio per dye concentration, it is the lowest and hence the least economical. It is perhaps surprising to note that at high protein concentrations, the uptake at $30^{\circ} \mathrm{C}$. is about twice that at $10^{\circ}$ C. (Fig. 5). This suggests that fluctuation in laboratory temperature can lead to disconcerting results and that thermostatic control of the staining procedure is advisable.

The author is grateful to Dr. D. H. Curnow for his interest throughout the course of this work and for his helpful criticism of the manuscript of this paper.

\section{REFERENCES}

Abdel-Wahab, E. M., and Laurence, D. J. R. (1955). Biochem. J., 60, xxxv.

Cremer, H. D., and Tiselius, A. (1950). Biochem. Z., 320, 273.

Dangerfield, W. G., and Smith, E. B. (1955). J. clin. Path., 8, 132. Discombe, G., Jones, R. F., and Winstanley, D. P. (1954). Ibid., 7,

106.
Franglen, G. (1956). In Ciba Foundation Symposium on Paper Electrophoresis, p.172. Churchill, London.

- and Martin, N. H. (1954). Biochem. J., 57, 626.

Gilliland, I. C., Johnston, R. N., Stradling, P., and Abdel-Wahab, E. M. (1956). Brit.med.J., 1, 1460 .

Gorringe, J. A. L. (1957). Clin. Chim. Acta, 2, 353.

Hardwicke, J. (1954). Biochem. J., 57, 166.

Henry, R. J., Golub, O. J., and Sobel, Ċ. (1957). Clin. Chem., 3, 49.

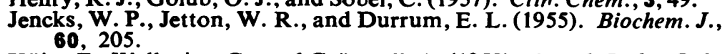

Köiw, E., Wallenius, G., and Grönwall, A. (1952). Scand. J. clin. Lab. Invest., 4, 47.

McDonald, H. J. (1952). J. chem. Educ., 29, 428.

- (1955). Ionography. Year Book Publishers, Chicago.

Foresman, J. L., and Bermes, E. W. (1957). Proc. Soc. exp. Biol. (N.Y.), 94, 493 .

Lappe, R. J., Marbach, E. P., Spitzer, R. H., and Urbin, M. C. (1953). Clin. Chemist, 5, 35.

Urbin. M.C., and Williamson, M. B. (1951). J. Amer. chem. Soc., $73,1893$.

Owen, J. A. (1956). Analyst, 81, 26.

Rappaport, F., Eichhorn, F., and Fisct.l, J. (1957). Clin. Chim. Acta, 2, 390 .

Rideout, L. A., and Prichard, R. W. (1955). Science, 121, 3'74.

Sunderman, F. W., Jr., Sunderman, F. W., Falvo, E. A., ard Kallick, C. J. (1958). Amer. J. clin. Path., 30, 112. 